\title{
Patrap Triloka Ethno-Pedagogy With Research-Based Learning Settings to Develop Capability of Pre-Service Science Teachers: Literature Review
}

\author{
$1^{\text {st }}$ Hasan Subekti \\ State University of Malang and State \\ University of Surabaya \\ Surabaya-INDONESIA \\ $4^{\text {th }}$ Hadi Suwono \\ State University of Malang \\ Malang, INDONESIA
}

\author{
$2^{\text {nd }}$ Herawati Susilo \\ State University of Malang \\ Malang, INDONESIA \\ herawati.susilo.fmipa@um.ac.id
}

\author{
$3^{\text {rd }}$ Ibrohim \\ State University of Malang \\ Malang, INDONESIA
}

\begin{abstract}
Student's capabilities are among the most commonly discussed research in higher education. In the Indonesian history, developing student capabilities is welldocumented aligning with Patrap Trilokathe - a local wisdombased education-. This was initially raised by $\mathrm{Ki}$ Hadjar Dewantara which was then scrutinized by the several universities in Indonesia (UM, UGM, UST, UNESA). This paper examines the literature about the thinking concept of Ki Hajar Dewantara in Patrap Triloka and its implication for the preservice science teachers' capabilities. This study was administered using an interdisciplinary perspective method, namely ethnic-pedagogy (the study of learning innovation that discusses the interaction between local wisdom and learning). The procedure used is as follows: (1) collecting literature and primary sources (Book 1 Ki Hajar Dewantara on Education); (2) analyzing the literature obtained, and (3) conceptualizing the outcomes of the investigation that has been conducted. The results of this study conclude two points: 1) the idea of Patrap Triloka ethnic-pedagogy implementation for the development of candidate capability of science teachers; 2) the conceptualization of capabilities for prospective science teachers is an individual's self-efficacy in applying theoretical concepts of science, pedagogy, developmental characteristics of learners, and building performance capabilities, communication, collaboration and mastery of digital technology through empirical experience. As well as attitudes (responsibilities) that take into account and apply the excellent culture of the Indonesian (gotong-royong, Bhinneka Tunggal Ika, courtesy) in known and new situations. Implications and recommendations for further research are described in this paper.
\end{abstract}

Keywords — Ethno-Pedagogy, Research Based-Learning

\section{INTRODUCTION}

Ethno-pedagogy is a local wisdom-based education practice and is derived from the cultural values of an ethnic [1] and becomes a standard of behaviour [2]. Ethno-pedagogy is construed as cultural values-based learning, which is cross or intercultural. Through ethno-pedagogical approach teachers in elementary schools can take a particular cultural setting and theme as a source of learning, especially local culture or local wisdom [3].

One of the local wisdom that has been studied and developed in several universities (including Gadjah Mada
University (UGM) [4], Surabaya State University (UNESA), State University of Malang (UM) [5], and Sarjanawiyata Tamansiswa University (UST) Yogyakarta) is Patrap Triloka raised by Ki Hadjar Dewantara. Patrap Triloka is system among local wisdom [6]. Patrap Triloka is inspired by the idea of $\mathrm{Ki}$ Hadjar Dewantara, which consists of three leadership principles [7], namely (a) ing ngarso sung tuladha or the first is being examples and guidance, (b) ing madya mangun karsa or in the midst play a role motivator or coach, and (c) tut wuri handayani or the last as supervisor [8]. The author argues that the Patrap Triloka has a potential and considerably urgent to develop in constructing the capability of perspective (adult) pre-service science teachers to live successfully in an advanced era.

Preparing graduates who are qualified, able to compete globally, and mastering the development of technology are urgent for everybody and essential towards the future of a country [9] whose lifestyle shifts rapidly. One of the triggers of the shift is the innovation and advancement of information technology (IT). This suggest that the mastery of technological developments and progress will be relatively adaptable and innovative through research activities. It is an essential part of the basic needs of everyone.

Research is one of the indispensable tools to improve the pearl of learning (10] and the quality of learning [11]. The application of ideas on research-based learning stems from the higher education of Humboldt's Vision. His notion "Universities should treat learning as consisting of not yet wholly solved problems and hence always in a research mode" [12]. This mission which is then underpinned as one of the UNESA science education's missions "... conducts innovative and research-based science education to produce environmentally-minded, entrepreneurial and global competitiveness" [13].

The student's capabilities that should be actualized in the work place including skills, knowledge, and attitudes. A capable student knows how to learn or study enthusiastically, to be creative, possesses in a high level of self-efficacy to implement his or her competences, and collaborate properly 
in any situations [14]. In the same way, the other capabilities, which are expected to strengthen the competence of students in taking part in the work place comprise: communication (written and oration) skill; critical thinking; analytical thinking, vigorous self-efficacy, and engaging in the universal cultural values (value systems, norms, beliefs, beliefs) [15]. Developing those capabilities to live successfully in the global era is an inevitable demand for students, particularly for pre-service science teachers through research activities.

As was mentioned in the description, a theoretical study on capability development related to research skills that are implemented with the local wisdom of Patrap Triloka. This present paper aims to validate the potential and urgency of Patrap Triloka ethno-pedagogy in developing specific research skills in the context of developing capabilities for the preservice science teacher.

\section{DISCUSSION}

This section discusses intensively several studies on the potential implementation of Patrap Triloka ethno-pedagogy to develop research skills. The study included (a) triloka patrap ethno-pedagogy, (b) research-based learning, and (c) the capability of the perspective of science's students.

\section{Patrap Triloka Ethno-pedagogy}

The phenomenon of the emergence of the term ethnopedagogy would be equivalent to the emergence of variants of the terms that embed the word pedagogy, such as ecopedagogy, ethnophilosophy, ethnopsychology, ethnopolitics, and so forth. This study particularly examined the dimensions of pedagogy through the perspective of pedagogical sociology that position Ethno-pedagogy within the pedagogical discipline. The discussion begins with the diversity of pedagogical contexts across cultures reflecting the nature of pedagogy and assessment trends associated with the development of pedagogical disciplines [16]. Ethnopedagogy is an educational practice based on local wisdom and sourced from the cultural values of ethnic and become a standard of behaviour that can be integrated into the learning; can be developed with other learning models such as inquiry and a combination of other models [17]. Practically, a local wisdom could be realized as sectional ideas of wisdom, full of wisdom, good worth, and suggestions for the glory of humans embedded and followed by members of the community or the mastery of local wisdom will carry their souls increasingly wise [18]. The implementation of education by teaching culture taken from issues can teach morality to students not only clarifying from values but also determining alternatives and consequences to take a stand in problem-solving [19].

Patrap Triloka or better known as the keeping systems [20] is one of the local wisdoms which was introduced by $\mathrm{Ki}$ Hadjar Dewantara. Patrap triloka constitutes full principals which asserts a teacher or lecturer as a dignified figure, who is expected to be a model, encouraging spirit, guidance, learning partners and directors also be authoritative and friendly with learners [4]. In the Indonesian community, this system is more familiar with the term tut wuri handayani [21]. The mechanism in implementing tut wuri handayani is adjusted to the age and education level of the students. The higher the students' age is, the more tut wuri is enlarged and handayani is minimazed. It follows that teachers are expected to arouse the willingness and the initiative to the adolescent student (ing madya mangun karsa), and give an example, guidance to the early age student (ing ngarsa sung tuladha).

Rationally, in this paper, the conceptualization of Patrap Triloka ethno-pedagogy is presented as the role of educator as part of the cultural activity which can posit the tenet (patrap) to coach and mentor the student. From this conceptualization, it is necessary to invoke and realise such as the integration of local wisdom values in developing the concept, model, or strategy in learning to answer the current global challenges. Concomitantly, the malfunction of Higher Education written in Law No. 12 of 2012 article 4 [22], namely "... to develop the ability and form the character and culture of a dignified nation so as educate the nation through the implementation of tri dharma (teaching, research, community service) and apply the value of humanities (eg attitude, affective, norm).

\section{Research-Based Learning}

Research-based learning is underpinned by a constructivism philosophy which includes four dimensions, namely (1) studying that constructs student understanding; (2) studying by developing basic knowledge (prior knowledge); (3) studying which is a process of social relationship; and (4) meaningful learning accomplished by way of manifest experience [4]. It is indeed related with the required tenet of the 21 st century education and those competences of students are also relevant to the needs of society and employment. In the light of pre-service science teacher's competences, it is urgently needed preparing them to comprehend the scientific knowledge, communication skill, collaboration skill, and master the information technology, economic, social and grasp with the cultural knowledge about Indonesia. This is in line with the Education Quality Priorities Guarantee Program for the preparation of learners in facing the challenges and opportunities of the 21st century [23] through a systematic and planned learning activity to foster an excellent academic culture and quality culture. One indicator of the growth of the cultures is characterized by artifacts, concepts, and behaviour as images of human creations and innovations [24].

In this study, the research skills were developed by taking into account six aspects of Research Skill Development (RSD), namely: (1) initiate an investigation, (2) find information or produce data (3) evaluate information or data; (4) manage information or data, (5) analyzing, synthesizing and applying new understandings, and (6) communicating research results with ethical, social and cultural awareness [25]. To foster those skills, students tend to be motivated in their learning through the completion of their research, or they do it directly. By doing so, students would be challenged in completing their research and they would also be driven by curiosity, eagerness, and self-indulgent to carry out their scientific activities.

\section{The Capability of Science Teacher Candidates}

Along with the vortex of time, we need to understand that science and technology evolve rapidly. This reality demands an urgency to increase the capability of mastery of science, especially for educators. The primary task of education is to educate students to prepare themselves for a successful life in the challenging $21^{\text {st }}$ century (digital age) [26]. 
Developing student capabilities is relatively crucial in the context of preparing them to face the work environment and the dynamics of change in the work place. The purpose of education is not to master the subject matter but to seek the provision of life to be successful [27]. Developing capability (28] [28] needs to be coherent and implemented in the right context. Therefore, the development requires a process [29]. The importance of educator's - lecturer- awareness about the world of students today, will be different from the world of the next ten years where they enter real life in society, so we ought to probe how the way we teach our students [30].

Improved capability can be fostered in various ways. The primary objective is to leave skilled and better-oriented, over perceptive, and useful individuals, and preferable policies to achieve development goals [31]. One of the innovations for improvement and challenging the concept of traditional learning by looking at the process and the results or known as the ability (capability). A person categorized capable are those who understand how to learn; creative; has a high level of self-efficacy; can adjust competence in familiar and new situations and work well with others. Differentiating competencies with capabilities are, capabilities that involve acquiring knowledge and skills, the capability is a holistic attribute [32].

In the 21st-century today the role of higher education becomes essential to equip the ability of students especially perspective teachers to be able to play an active role in developing capabilities. The necessary skills needed by educators regarding $21^{\text {st }}$-century skills are critical thinking, problem-solving, collaborative learning, student-centered learning, and digital literacy [33]. Similarly, $21^{\text {st }}$ century skills methodological requirements of assessment formulated $21^{\text {st }}$-century skills into three general skills: (1) problem solving, (2) collaborative problem solving (3) learning through digital networks [34]. Individuals need to have competencies in 5 primary skills, namely: (1) able to adjust; (2) complex communication skills; (3) problem-solving skills; (4) self-organizing skills; and (5) system of thought [35]. The $21^{\text {st }}$-century capability that young people need to keep in mind and possess such as life and career skills, learning and innovation skills, and information media and technology skills. This discourse is in line with Permenristekdikti No.13 of 2015 article 20 which states the ability to think critically-creatively, problem-solving, communication, negotiation, teamwork, and leadership [36].

Individual capability within an organization (in the context of this research school or college), is the inevitable change that is expected to be made in the globalization and liberalization era [29]. By ignoring and not following the development of science and technology, predicted not included in the system and the growing community of science circle. In this context, the urgency of innovation through contemporary research activities to contribute provides insight and pillar of educational development. Based on the reference of the study, the conceptualization of capability for the preservice science teacher "is an individual's self-efficacy in applying its competence (mastering knowledge [theoretical concepts of science, pedagogy, developmental characteristics]), and building performance skills critical, problem-solving, communication, collaboration, and mastery of digital technology] through empirical experience, and attitudes [responsibilities]) that take into account and apply the humanitarian value well in known and new situations.

\section{CONCLUSION}

Based on the literature review that the author has done, several conclusions can be taken as follows.

1. The idea of Patrap Triloka ethno-pedagogy implementation has the potential to develop the capability of the perspective of pre-service science teachers.

2. The conceptualization of capability for the preservice science teacher "is an individual's self-efficacy in applying its competence (mastering knowledge [theoretical concepts of science, pedagogy, developmental characteristics]), and building performance skills [problem-solving, critical thinking, collaboration, communication, and mastery of digital technology] through empirical experience, and attitudes [responsibilities]) that take into account and apply the human and cultural values of both Indonesian in known and new situations.

\section{ACKNOWLEDGMENT}

The researcher thanked the Ministry of Research, Technology, and Higher Education (Kemristekdikti) of the Republic of Indonesia who had funded this study. Besides, the author would like to thank Prof. Dr. Duran Corebima Aloysius, M.Pd., and Prof. Dr. Siti Zubaidah, S.Pd., M.Pd., who has been accompanied on developing instruments, writing reports and scientific publications through lecturing process on the Writing Articles for International Journals.

\section{REFERENCES}

[1] Albaiti. Kajian Kearifan Lokal Kelompok Budaya Dani Lembah Baliem Wamena Papua. J Pendidik Nusant Indones;1(1):14-33 (2015).

[2] N.Y. Rustaman. Pemberdayaan Entrepreneurship: Implementasi TeoriU dalam Bioteknologi Praktis Berbasis STEM. In Semarang; p. 529.(2016).

[3] Z. A., Khusainov, and S. S Galimov. Education of ecological culture of schoolchildren from ethno pedagogy. Life Sci J.11(9):260-264 (2014).

[4] D.T. Widayati, D. Luknanto, E. Rahayuningsih, G. Sutapa, Harsono, R. P. Sancayaningsih, Sajarwa, Suwardjono, \& H. C Yohannes. Guidelines Research-Based Learning. $1^{\text {st }}$ ed. Yogyakarta: Universitas Gadjah Mada; p. 3-5 (2010).

[5] M.N. Wangid. Sistem Among pada Masa Kini: Kajian Konsep dan Praktik Pendidikan. J Kependidikan; 39(2):129-40 (2009).

[6] Universitas Gadjah Mada (UGM). Panduan Penyusunan Proposal Program Hibah Pembelajaran Student Teacher Aesthetic Role-sharing (STAR). Pusat Pengembangan Pendidikan (P3) UGM; (2010).

[7] H. Suwignyo. Manifestasi Tindak Tutur Pembelajaran Among dalam Wacana Kelas. J Pendidik Dan Pembelajaran. 17(2):147 (2010).

[8] H. Suwignyo. Tuturan Laku Among dalam Wacana Kelas. Bahasa dan Seni. 39(1):9 (2011).

[9] H. Kanematsu, M.D. Barry. STEM and ICT Education in Intelligent Environments [Internet]. $1^{\text {st }}$ ed. Vol. 91. Japan: Springer International Publishing; 2016 , http://www.springer.com/in/book/9783319192338 (2016).

[10] W. Widodo. Literasi Sains Mahasiswa Calon Guru IPA Berdasarkan Permintaan Kognitif (Cognitive Demand) PISA: Bagaimana Langkah Selanjutnya? In: Proceedings of Invited Papers. Unesa, Surabaya: Pendidikan Sains (2016).

[11] H. Subekti, dan Martini. Representasi Pembelajaran Berbasis Penelitian pada Mata Kuliah Bioteknologi dan Salingtemas dalam Menumbuhkan Budaya Akademik di Program Studi Pendidikan IPA Unesa. In: Pendidik IPA Inovatif yang Berdaya Saing dalam Masyarakat Ekonomi ASEAN (MEA). Universitas Negeri Semarang: Jurusan IPA Terpadu. p. 598-607 (2016), see: 
https://drive.google.com/file/d/0B3RNMhiky2k4bFViRmVBcjgtRTA /view? usp=sharing.

[12] S. Blume, N. Madanchi, S. Böhme, G. Posselt, S. Thiede, and C. Herrmann. Die Lernfabrik - Research-based Learning for Sustainable Production Engineering. Procedia CIRP. 32:126-31 (2015).

[13] Pendidikan Sains. Laporan Kegiatan Uji Publik: dalam Rangka Pengembangan Kurikulum Progam Studi Penerima Hibah Kurikulum PIU-IDB Unesa. FMIPA Unesa (2016).

[14] H. Susilo, Ibrohim, and H. Suwono. Pengembangan Kapabilitas Peserta Didik Melalui Belajar Berbasis Kehidupan dalam Pembelajaran Biologi: Usulan Penelitian Tim Pascasarjana. LP3 UM (2016).

[15] Kemristekdikti. Pengayaan Mata Kuliah Umum Melalui General Education. Direktorat Jenderal Pembelajaran dan Kemahasiswaan (2016).

[16] T. Suratno, Memaknai Ethno-pedagogy sebagai Landasan Pendidikan Guru di Universitas Pendidikan Indonesia. In: Proceedings of Invited Papers The 4th International Conference on Teacher Education 8-10 $\begin{array}{lllll}\text { November } & \text { p. } & 519 & \text { (2010): } & \text { UPI; }\end{array}$ http://file.upi.edu/Direktori/proceeding/UPI-

UPSI/2010/Book_3/memaknai_etnopedagogi_sebagai_landasan_pend idikan_guru_di_universitas_pendidikan_indonesia.pdf

[17] U. Toharudina, I. S. Kurniawan. Sundanese Cultural Values of Loca Wisdom: Integrated to Develop a Model of Learning Biology. Int J Sci Basic Appl Res IJSBAR. 32(1):30 (2017).

[18] Y.T. Herlambang. Pendidikan Kearifan Etnik dalam Mengembangkan Karakter. Eduhumaniora J Pendidik Dasar. 7(1):1-11 (2015).

[19] J. W. Santrock. Psikologi Pendidikan. 5th ed. Jakarta: Salemba Humanika; 2014. p.177. See: https://www.belbuk.com/psikologipendidikan-buku-1-edisi-5-p-12074.html

[20] I.D. Ana, Harsono, E. Rahayuningsih. Student Teacher Aesthetic Rolesharing (STAR): A Local-wisdom Based Approach to Build Graduate"s Character. Proceedings of Invited Papers. In: Enhancing Employability through Quality Assurance [Internet]. Kelaniya, Sri Lanka: University of Kelaniya; (2014) p. 96-102. See: http://www.kln.ac.lk/wp-content/uploads/2014/06/SubThemeA6.pdf

[21] H. Subandiyah. Pengembangan Model Pembelajaran Apresiasi Sastra Berdasarkan Teori Respon Pembaca dan Sistem Among. Surabaya: Universitas Negeri Surabaya (2012), see: http://pusinfounesa.blogspot.co.id/2012/11/disertasi-pascasarjanaunesa-november_30.html

[22] Undang-undang Republik Indonesia (UU R1) No 12 Tahun 2011 tentang Pendidikan Tinggi.

[23] S. Subandi. Multilateral Meeting dalam Rangka Penyususunan RKP 2017 Pembangunan Nasounal Pembangunan Pendidikan: Selaku Deputi Bidang Pembangunan Manusia, Masyarakat, dan Kebudayaan. 2016 Feb 23; Jakarta, see:: http://akademik.unand.ac.id/images/imgdemo/Beasiswa/General-Education-2016.pdf

[24] Suyatno. Metode Kepramukaan untuk Pembina dan Pelatih Pramuka. Mustika Ilmu; (2016) iii.

[25] J.Willison. When academics integrate research skill development in the curriculum. High Educ Res Dev; 31(6):905-19 (2012).

[26] H. Suwono. Aktivitas Belajar Mahasiswa Calon Guru Melalui Penerapan Blended Learning Menggunakan Website Berbasis Moodle. In Malang: FMIPA UM.

[27] M. Samani. Tiga Problem Mendasar Pendidikan di Indonesia. In Surabaya: ISPI; (2014).

[28] P. Sudira. Life-Based Learning dalam Pendidikan Teknologi dan Vokasional. Tanpa Tahun. See http://staffnew.uny.ac.id/upload/131655274/penelitian/life-basedlearning.pdf. p. 2

[29] J. Morely Teaching English as a second or foreign language. In: Aural Comprehension Instruction: Principles and Practices. (3rd ed). Boston: Heinle \& Heinle; p. 69-85, see: http://gaining.educ.msu.edu/resources/files/Teaching\%20listening.Mo rley\%202001.pdf

[30] H. Susilo. Blended Learning untuk Menyiapkan Siswa Hidup di Abad 21. In Malang; See: http://www.scribd.com/doc/73445705/BlendedLearning-Untuk-Menyiapkan-Siswa-Hidup-di-Abad-21 p.22

[31] D. Kumar, D. Changappa, and S. Pandya. Capability Development: Enhancing Employee Potential through Strategic Competency Building and People Development. Int J Manag Soc Sci Res IJMSSR. 2(2):27-32.
[32] S. Hase Measuring Organisational Capability: Beyond Competence. In: Australian Capability Network. Reference: Hase, S. (2000) 'Measuring organisational capability,' AVETRA conference, Sydney: Southern Cross Business School; 2000, see http://www.avetra.org.au/abstracts_and_papers_2000/shase_full.pdf.

[33] I. Kennedy, L. Gloria, J. Hélia. Education Skills for $21^{\text {st }}$ Century Teachers: Voices From a Global Online Educators' Forum. 1st ed. London: Springer in Education, (2016). P 21. See DOI 10.1007/978-3319-22608-8.

[34] P. Griffin, and C. Esther, editors. Assessment and Teaching of 21st Century skills. 1st ed. London: Springer Science; (2016). p.12. see http://www.springer.com/gp/book/9789401793940.

[35] National Research Council (NRC). Assessing $21^{\text {st }}$ Century Skills: Summary of a Workshop. J.A. Koenig, Rapporteur. Committee on the Assessment of $21^{\text {st }}$ Century Skills. Committee on the Assessment of $21^{\text {st }}$ Century Skills.

[36] B. Trilling, and C. Fadel. $21^{\text {st }}$ Century Skills: Learning for Life in Our Times. John Wiley \& Sons London; (2009). P.75. 